\section{Pacific Northwest} National Laboratory

Operated by Battelle for the

U.S. Department of Energy

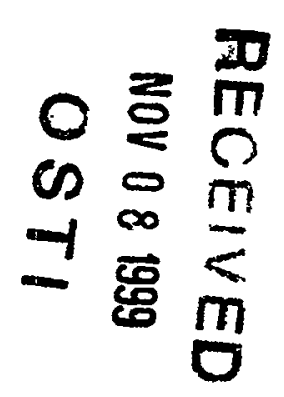

Steelhead Spawning Surveys Near Locke Island, Hanford Reach of the Columbia River

R. P. Mueller

D. R. Geist

October 1999

Prepared for the U.S. Department of Energy

Contract DE-AC06-76RLO 1830 


\section{DISCLAIMER}

This report was prepared as an account of work sponsored by an agency of the United States Government. Neither the United States Government nor any agency thereof, nor Battelle Memorial Institute, nor any of their employees, makes any warranty, express or implied, or assumes any legal liability or responsibility for the accuracy, completeness, or usefulness of any information, apparatus, product, or process disclosed, or represents that its use would not infringe privately owned rights. Reference herein to any specific commercial product; process, or service by trade name, trademark, manufacturer, or otherwise does not necessarily constitute or imply its endorsement, recommendation, or favoring by the United States Government or any agency thereof, or Battelle Memorial Institute. The views and opinions of authors expressed herein do not necessarily state or reflect those of the United States Government or any agency thereof.

\section{PACIFIC NORTHWEST NATIONAL LABORATORY operated by \\ BATTELLE for the UNTTED STATES DEPARTMENT OF ENERGY under Contract DE-AC06-76RLO 1830}

Printed in the United States of America

Available to DOE and DOE contractors from the Office of Scientific and Technical Information, P.O. Box 62, Oak Ridge, TN 37831; prices available from (615) $576-8401$.

: Available to the public from the National Technical Information Service, U.S. Department of Commerce, 5285 Port Royal Rd., Springfield, VA 22161

This document was printed on recycled paper. 


\section{DISCLAIMER}

Portions of this document may be illegible in electronic image products. Images are produced from the best available original document. 
PNNL-13055

\title{
Steelhead Spawning Surveys Near Locke Island, Hanford Reach of the Columbia River
}

\author{
R. P. Mueller \\ D. R. Geist
}

October 1999

Prepared for

the U.S. Department of Energy

Contract DE-AC06-76RLO 1830

Pacific Northwest National Laboratory

Richland, Washington 99352 



\section{Executive Summary .}

In 1997, the National Marine Fisheries Service (NMFS) listed upper Columbia River steelhead trout (Oncorhynchus mykiss) as endangered. This action affected management of land-use activities along and within the Hanford Reach of the Columbia River, which flows through the U.S. Department of Energy (DOE) Hanford Site. Steelhead covered in this listing include all naturally spawned populations of steelhead and their progeny in streams in the Columbia River Basin upstream from the Yakima River to the United States/Canada border. The NMFS has identified a general listing of activities that could potentially result in harm to steelhead ( 62 FR 43937, August 18, 1997). One of these concerns includes landuse changes resulting in mass wasting or surface erosion.

Landslide activity along the White Bluffs on the east side of Locke Island has redirected river flow into the island where substantial erosion has occurred. This erosion has exposed important anthropological and archaeological resources that were previously buried on the island. The DOE is working with affected tribes and other agencies to develop a plan for addressing the erosion of Locke Island. As part of this effort, the U.S. Army Corps of Engineers has prepared an assessment of potential alternatives to stabilize the erosion, including a no-action alternative. Steelhead historically spawned in the vicinity of Locke Island, but recent information on the occurrence of steelhead spawning or availability of spawning habitat was lacking. Therefore, the purpose of this study was to determine if steelhead spawned in the vicinity of Locke Island erosion and to evaluate the composition of substrate in the affected area.

Surveys to document the occurrence of steelheads redds were conducted in Spring 1999. The surveys were conducted from the air as well as with the use of an underwater video camera. Neither aerial nor underwater surveys documented steelhead spawning within the survey area. Habitat surveys were conducted in July 1999. The survey area was divided into an area adjacent to the erosion zone and an area immediately upstream of this zone. The majority of the survey area was composed of gravel and medium cobble (particle sizes 0.6 to $15.2 \mathrm{~cm}$ ). Aquatic vegetation (milfoil) was found in the upstream section, indicating lower water velocities not conducive to steelhead spawning. Based on the available substrate within the entire survey area, we estimate $81 \%$ of survey site could be used by adult steelhead for spawning. 



\section{Acknowledgments}

The authors thank Corey Duberstein, Joanne Duncan, Rhett Zufelt, and Russ Moursund of Pacific Northwest National Laboratory (PNNL) for providing valuable technical support. We also thank Dennis Dauble of PNNL and Steve Richards of the Washington Department of Fish and Wildlife, who conducted aerial surveys and provided a summary of flight conditions. Funding for this project was provided by the U.S. Department of Energy and the Bonneville Power Administration under contract 27002A. 



\section{Contents}

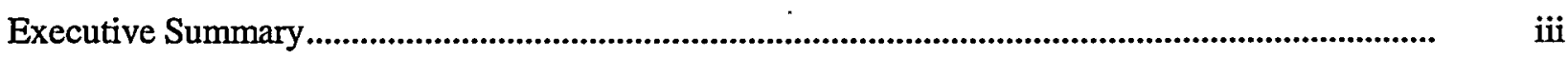

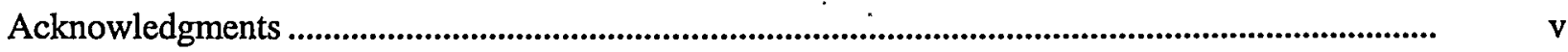

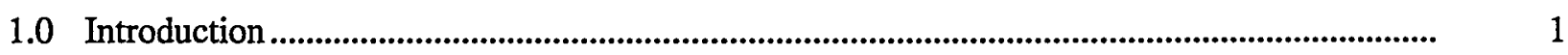

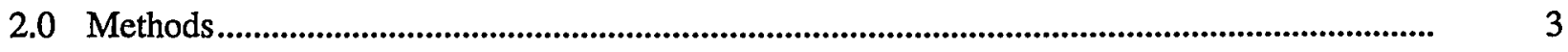

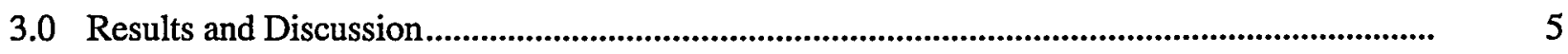

3.1 Aerial/Spawning Surveys........................................................................................ $\quad 5$

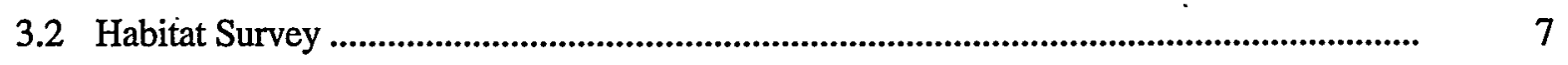

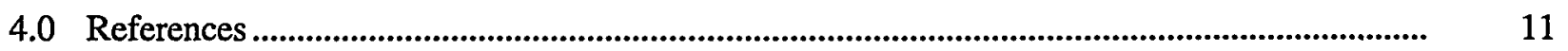

\section{Figures}

1 Map of Study Areas and River Transects in Relation to the Hanford Reach and

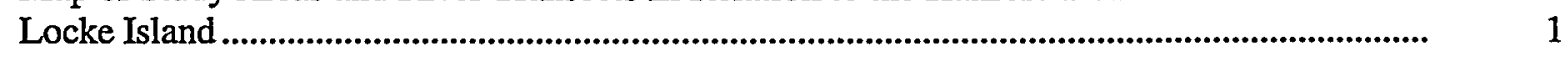

2 Digitized Image of Substrate and Laser Reference Markers................................................. 4

3 Location of Steelhead Redds Observed During Aerial Surveys in 1968 Near Locke Island.... 6

4 Estimated Distribution of Substrate Occurring Within the Eastern Portion of the Columbia River Near Locke Island .....................................................................................

5 Estimated Distribution of Milfoil Occurring Within the Eastern Portion of the

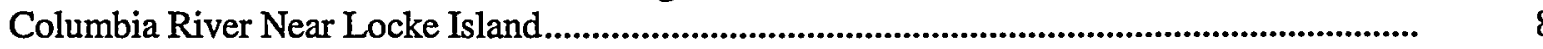

6 Water Depth Data Gathered Using a Scanning Hydrographic Operational Airborne Lidar Survey System 


\section{Tables}

1 Substrate Categories Used for Spawning Habitat Classification ............................................. . 4

2 Conditions Observed During the Aerial Redd Surveys of the Hanford Reach Conducted by PNNL and WDFW in 1999.

5

3 Estimated Distribution of Substrate by Location Within the Survey Area ................................. 7 


\subsection{Introduction}

Locke Island is located within the Hanford Reach of the Columbia River at river kilometer 595.4 (Figure 1). During the last 5 years, a significant amount of bank erosion has occurred on the eastern portion of Locke Island. This erosion is due, in part, to the recent slumping of the White Bluffs shoreline and resultant displacement of flow toward the northeast side of Locke Island. The main impact on the island erosion is the loss of archeological resources that have significant cultural importance. To help prevent continued erosion of Locke Island, an erosion control plan was developed by the U.S. Army Corps of Engineers (USACOE 1998). The plan lists several alternatives (including no-action) that have the potential to affect steelhead (Oncorhynchus mykiss), which currently are listed as endangered under the Endangered Species Act (ESA).

Information on the quantity and location of steelhead spawning is sketchy because aerial surveys of steelhead spawning are difficult, if not impossible, because of high, turbid spring runoff that obscures visibility. Steelhead likely spawn in the Hanford Reach between February and early June, with peak spawning in mid-May (Eldred 1970; Watson 1973; Becker 1985).

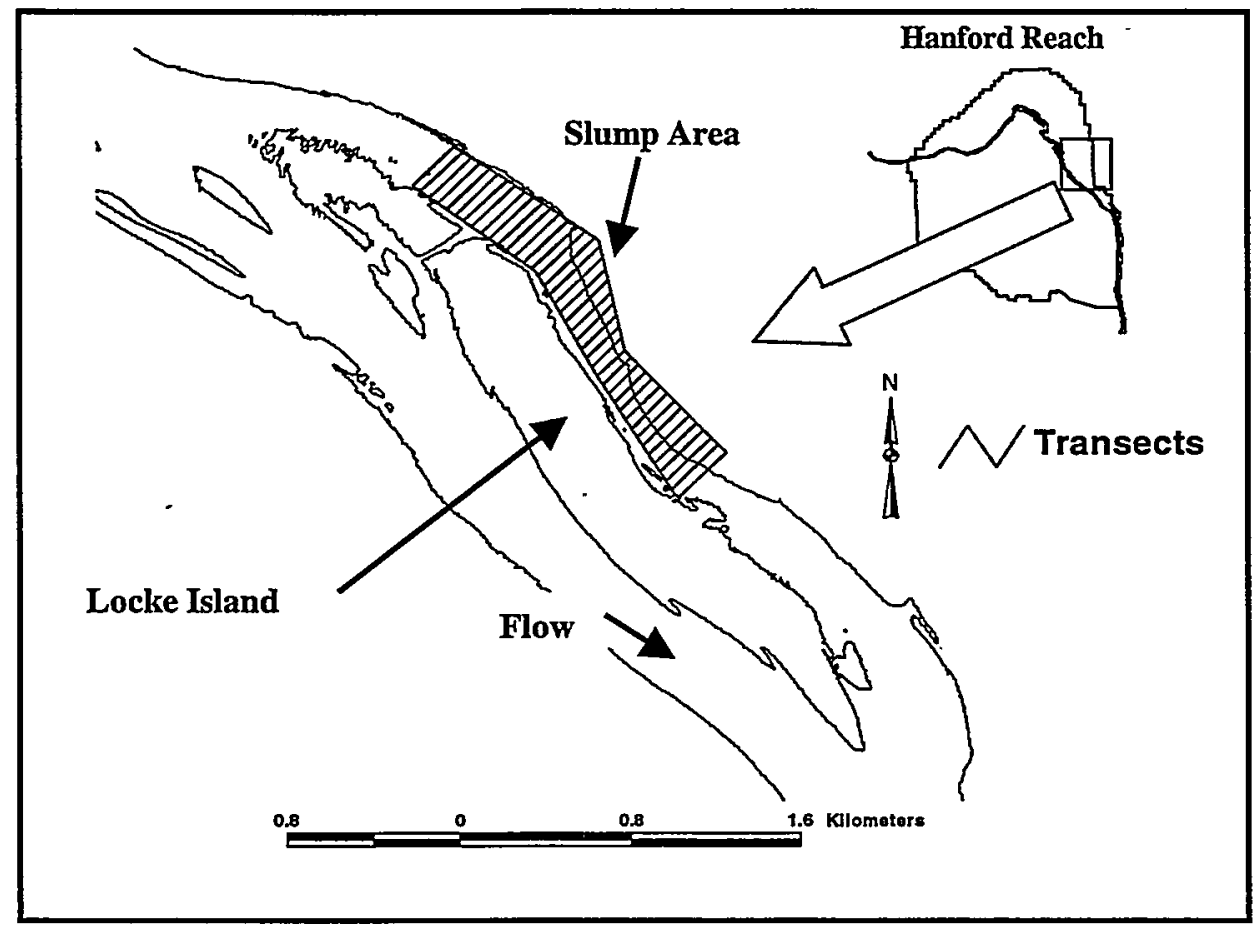

Figure 1. Map of Study Area and River Transects in Relation to the Hanford Reach and Locke Island 
Key spawning areas reported from aerial surveys conducted in 1968 and 1970 included Vernita Bar, Coyote Rapids, Locke Island, 100-F islands, and Ringold (Tony Eldred, personal communication with D.R. Geist 9-28-89). A total of 220 redds were counted in 1968 and 95 in 1970; total steelhead spawning was estimated by Eldred to be approximately 2,200 to 25,000 in 1968 and 950 to 7,800 in 1970. Gray and Dauble (1976) collected gravid and ripe steelhead females in late April and early May and spent males in August within the Reach. Fickeisen et al. (1980) indicated steelhead trout likely spawned at Vernita Bar, Coyote Rapids, Locke Island, and Ringold.

Watson (1973) constructed a "steelhead budget" and compared the number of fish entering the Reach with fish remaining after taking into consideration steelhead counts at upstream dams, tributary escapement, natural mortality, and sport harvest. He estimated that of the 35,000 steelhead that annually passed McNary Dam from 1962 to 1971, approximately 13,000 (range -15,259 to 40,823) were unaccounted for and potentially spawned within the Hanford Reach. In a similar study for the period 1977 through 1996, an estimated 9,000 steelhead (range $-15,259$ to 40,158 ) may currently spawn within the Hanford Reach (PNNL unpublished data). Even after taking into consideration fall back at McNary Dam, this number could be several thousand.

Since 1970, there has been little effort to document steelhead spawning in the Hanford Reach. A limited survey was completed in 1998 by Pacific Northwest National Laboratory (PNNL). The aerial surveys found approximately 75 redds occurring near Ringold and F-Slough (D.D. Dauble, PNNL personal communication). High flows restricted the ability to confirm these sightings as steelhead redds using underwater video.

Since the listing of steelhead under the ESA in 1997, there has been a higher priority to document locations of any steelhead spawning that occurs in the Reach so Hanford Site activities can be managed to avoid impacts to listed species. Because the Locke Island erosion control plan includes alternatives that have the potential to affect steelhead habitat, additional information on steelhead habitat use in the vicinity of Locke Island was needed. Therefore, the purpose of this study was to locate steelhead spawning in the vicinity of Locke Island and to characterize the habitat in the area that could be impacted. 


\subsection{Methods}

Aerial surveys to locate steelhead spawning in the Hanford Reach were conducted using a fixed-wing aircraft. An effort was made to conduct the surveys during the primary steelhead spawning period when flows were low. Researchers flew the entire Hanford Reach and noted any potential redds on a map. Special attention was given to areas where previous aerial surveys had documented redds. PNNL and the Washington Department of Fish and Wildlife (WDFW) conducted eight redd surveys during April and May 1999.

Two underwater surveys were conducted adjacent to Locke Island where shoreline slumping has occurred. The first survey occurred May 6 and 7, 1999, to determine if any steelhead redds existed within the survey area. The second survey was conducted on July 30,1999, to characterize the potential spawning habitat (defined by water depth and substrate size): Over the two surveys, a total of 41 transects were run at 50-m intervals between Locke Island and the White Bluffs shoreline (Figure 1). The average transect length was $250 \mathrm{~m}$. The data were grouped into two categories: (1) area upstream of the slump, and (2) area adjacent to the bank slumping.

The mobile underwater video system used was composed of a high-sensitivity remote camera (Sony, model HVM-352) attached to a weighted platform. Recordings were made using a Sony model CCDFX710 Handycam located on the motorboat. Two high-resolution monitors were used during the surveys for better viewing of the video obtained by the remote camera. The location for each image (UTM X and UTM Y) was correlated to global positioning system (GPS) location by a time stamp.

Two lasers pointed downward, $18.4 \mathrm{~cm}$ apart were attached to the underwater platform and were used to provide a reference scale within the camera image (Figure 2). The distance from the camera lens to the substratum ranged from 0.9 to $1.4 \mathrm{~m}$, providing an effective view path of $2.7 \mathrm{~m}^{2}$. Changes in background contrast, bed elevation, or substrate composition were the primary criteria used to determine spawning activity. Recorded tapes were reviewed in detail at the PNNL computer lab using a high-resolution monitor.

An on-board, real-time GPS (Trimble Pathfinder ${ }^{\mathrm{TM}}$ Pro XR) was used to collect positional data as well as to navigate a pre-set transect grid during the surveys. The integrated GPS beacon receiver and . antenna provided GPS corrections for calculating sub-meter accuracy (approximately $0.5 \mathrm{~m}$ ) on a secondby-second basis, and thus eliminated the use of a surveyor to capture positional information of the boat during surveys. Longer data point acquisitions provided positions with greater than $0.5-\mathrm{m}$ accuracy. The system's software (ASPEN) displayed a background map of the study site on a personal computer so researchers could navigate to site locations on a pre-determined transect line or visually verify data accuracy in the field.

The substratum mapping survey was conducted using the same grid as that used in the redd survey in May. Transects were conducted using a pre-set grid of 41 transects at 50-m intervals (Figure 1). A minimum of five locations along each transect were selected for substratum composition. Particle size was determined by taking an average of the dominant substrate type at each location. A circular 25-m 


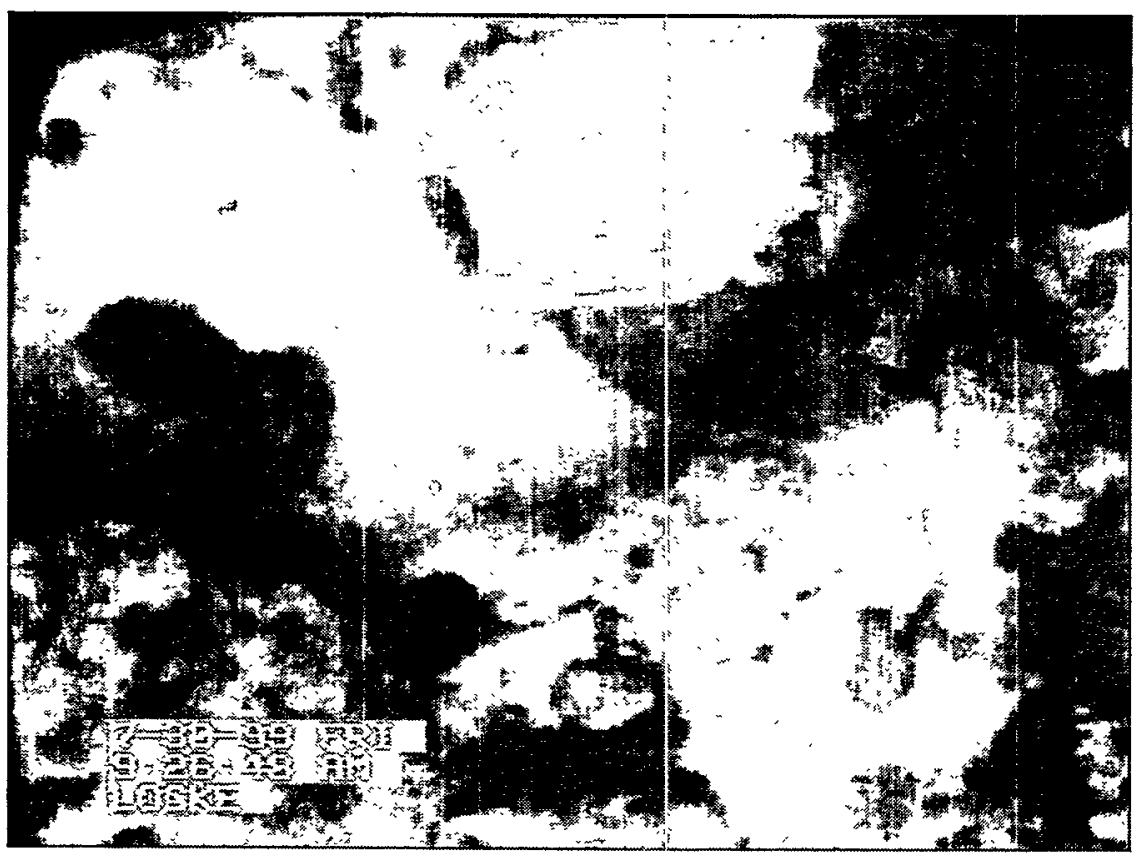

Figure 2. Digitized Image of Substrate and Laser Reference Markers. Distance between laser points is $18.4 \mathrm{~cm}$.

buffer was used to extrapolate the particle size to the surrounding area. Because of uneven spacing on locations along each transect, some overlap of the 25 -m circular buffer occurred. Each video image was assigned a dominant substrate class (Table 1) based on long-axis diameter. Dominant substrate was the predominant size class of substrate size based on surface area. The boundaries of each buffer and the corresponding substrate classification were traced and then digitized into the geographic information system (GIS).

To determine if substrate suitable for spawning occurred within the survey area, the data were compared to steelhead habitat previously described for the Clearwater River, Idaho (Orcutt et al. 1968). The preferred gravel sizes used by adult steelhead in this study ranged from 1.3 to $10.2 \mathrm{~cm}$.

Table 1. Substrate Categories Used for Spawning Habitat Classification (modified from Platts et al. 1983)

\begin{tabular}{|c|l|l||}
\hline Category & \multicolumn{1}{|c|}{ Sediment Classification } & \multicolumn{1}{|c|}{$\begin{array}{c}\text { Long Axis Diameter of } \\
\text { Individual Substrate (cm) }\end{array}$} \\
\hline \hline 1 & Gravel & $0.6-7.6$ \\
\hline 2 & Medium cobble & $7.6-15.2$ \\
\hline 3 & Large cobble & $15.2-30.5$ \\
\hline 4 & Boulder/bedrock & $>30.5$ \\
\hline
\end{tabular}




\subsection{Results and Discussion}

This section reports results for both the aerial spawning surveys conducted by PNNL and WDFW and the habitat survey.

\subsection{Aerial/Spawning Surveys}

No steelhead redds were detected during any of the aerial surveys conducted by PNNL or WDFW during April and May 1999. During these surveys, the river flow measured at Priest Rapids Dam ranged from 143 to $190 \mathrm{kcfs}$ (Table 2). To protect stranding of fall chinook salmon fry in the Hanford Reach, the outflow at Priest Rapids was more uniform than in previous years. These uniform flows hampered our ability to survey on weekends when flows normally drop. In addition, water clarity was estimated to be less than $1.8 \mathrm{~m}$. A few patches of possible redds were noted near F-Slough and Ringold, but these were later discounted as underwater clay deposits.

Table 2. Conditions Observed During the Aerial Redd Surveys of the Hanford Reach Conducted by PNNL and WDFW in 1999

\begin{tabular}{||l|l|c|l|l|l|c||}
\hline $\begin{array}{c}\text { Survey } \\
\text { Date } \\
(1999)\end{array}$ & $\begin{array}{c}\text { Organization } \\
\text { Conducting } \\
\text { Survey }\end{array}$ & $\begin{array}{c}\text { Approx. River } \\
\text { Q (kcfs) During } \\
\text { Survey }\end{array}$ & Wind & $\begin{array}{c}\text { Cloud } \\
\text { Cover }\end{array}$ & $\begin{array}{c}\text { Depth of } \\
\text { Visibility }\end{array}$ & $\begin{array}{c}\text { General } \\
\text { Viewing } \\
\text { Conditions }\end{array}$ \\
\hline \hline April 2 & PNNL & 144 & Calm & Partial & $<1.8 \mathrm{~m}$ & Good \\
\hline April 8 & WDFW & 143 & Light & Partial & $<1.8 \mathrm{~m}$ & Good \\
\hline April 22 & PNNL & 170 & Light & Partial & $<1.8 \mathrm{~m}$ & Good \\
\hline April 26 & WDFW & 160 & Light & Clear & $<1.8 \mathrm{~m}$ & Good \\
\hline May 5 & PNNL & 190 & Light & Clear & $<1.8 \mathrm{~m}$ & Good \\
\hline May 13 & PNNL & 156 & Light & Partial & $<1.8 \mathrm{~m}$ & Good \\
\hline May 19 & WDFW & 155 & Calm & Clear & $<1.8 \mathrm{~m}$ & Good \\
\hline May 27 & WDFW & 175 & Calm & Clear & $<1.8 \mathrm{~m}$ & Good \\
\hline
\end{tabular}

The spawning survey using the underwater camera consisted of a total of 41 boat transects that ran perpendicular to the shoreline. The average river flow during these surveys was $168 \mathrm{kcfs}$. The water clarity was estimated at $1.2 \mathrm{~m}$ for the two underwater video surveys conducted on May 6 and 7, 1999. These surveys did not document any obvious redds within the survey area. A large area of very clean gravel and cobble occurred adjacent to the slump area close to Locke Island, but no evidence of recent spawning activity was observed. The limited water clarity resulted in having to run the camera closer to the river bottom, which made detection of redds difficult. 
It is not clear if our inability to find redds was because no redds were present, or because conditions to see them were less than optimal. Based on aerial surveys, steelhead have been known to use the river channel around Locke Island (Eldred 1970); the majority of the spawning occurred on the eastern part of the Island (Figure 3). The 1968 surveys indicated that spawning occurred throughout the slump area but were confined to the Locke Island side of the river channel. The 1968 survey did not document redds in the area upstream of the slump. Thus, it seems likely that the Locke Island area could be used by steelhead for spawning. Our survey may not have been successful because discharge was high, and visibility was low. River discharge during our surveys ranged from 143 to $190 \mathrm{kcfs}$. For comparison, information on steelhead spawning from the 1968 survey was collected during unusually low flow conditions (40 to $76 \mathrm{kcfs}$ ). The higher discharge during our surveys may have masked potential spawning. Additional surveys under low flow conditions will likely be needed to conclusively demonstrate steelhead spawning in the channel on the northeast side of Locke Island.

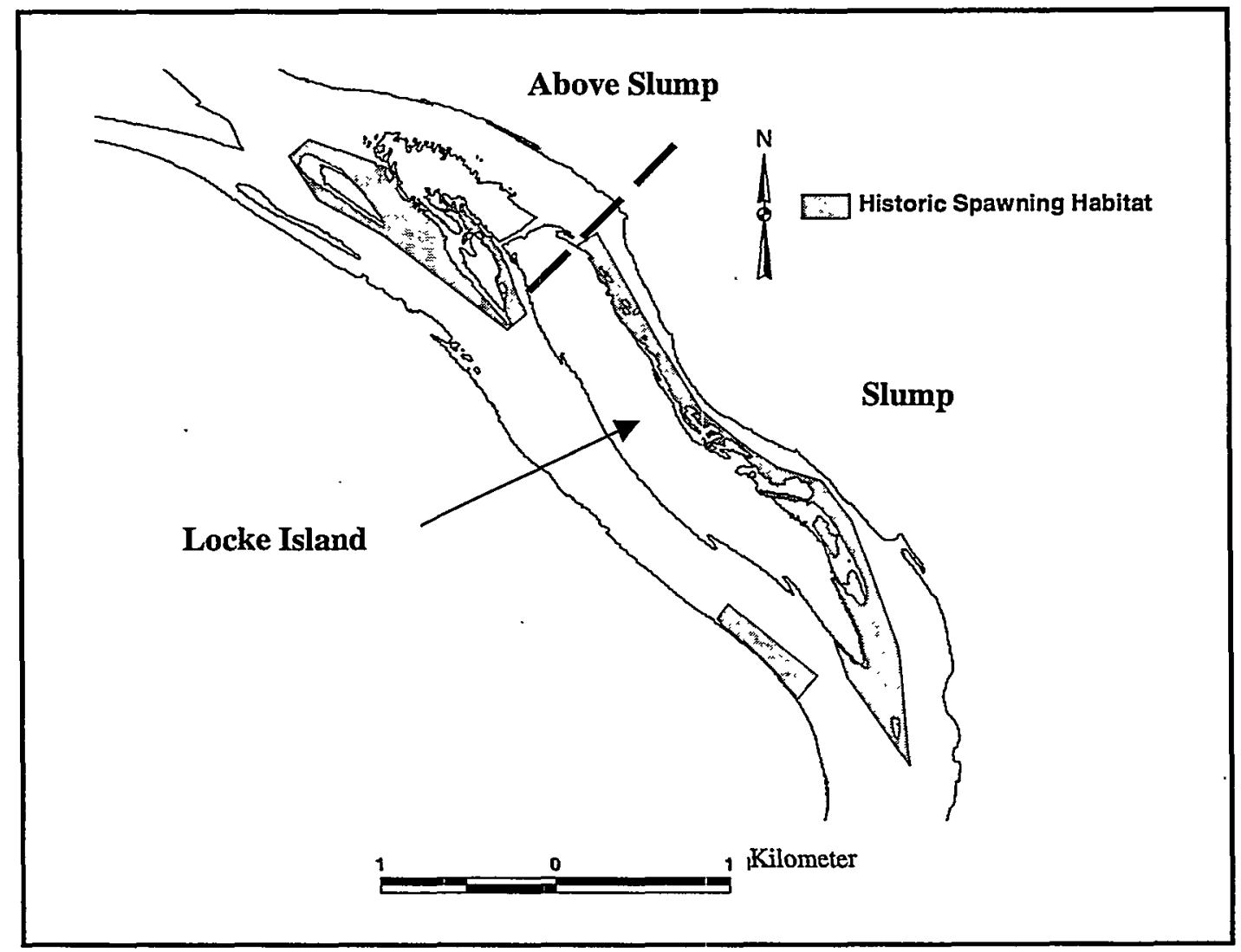

Figure 3. Location of Steelhead Redds Observed During Aerial Surveys in 1968 Near Locke Island (Eldred 1970) 


\subsection{Habitat Survey}

The habitat survey was conducted on July 30,1999 . The survey was conducted using the same grid as that used for the spawning survey. The average river flow during the habitat survey was $103 \mathrm{kcfs}$. A total of 228 survey points were analyzed to characterize the substratum over the entire survey area. Using the $25-\mathrm{m}$ buffers, the total substratum characterized was estimated to be $306,895 \mathrm{~m}^{2}$. Approximately $37 \%$ of the entire survey area was not categorized due to water depth, variable data points, or the presence of milfoil. The water clarity for the July survey was estimated to be $2.8 \mathrm{~m}$, which was considerably better than that observed during the spring surveys.

Of the area we could survey, approximately $52 \%$ was found to contain medium cobble as the dominant substrate followed by gravel and bedrock (Table 3). A comparison of the survey area influenced by the slump and the area surveyed upstream of the slump showed medium cobble as the most abundant substrate type in each area. Following medium cobble, gravel, large cobble, and bedrock were equally distributed in the area upstream of the slump while gravel was the second most abundant substrate type within the slump area. A plan view shows that the substrate type is mostly composed of medium cobble with bedrock along the eastern side where the river channel is wider (above slump) (Figure 4). In

Table 3. Estimated Distribution of Substrate by Location Within the Survey Area

\begin{tabular}{||l|c|c|c|c|c|c||}
\hline \multicolumn{1}{|c|}{ Categories } & $\begin{array}{c}\text { Above Slump } \\
\left(\text { area m }^{2}\right)\end{array}$ & $\%$ & $\begin{array}{c}\text { Within Slump } \\
\left(\operatorname{area~m}^{2}\right)\end{array}$ & $\%$ & $\begin{array}{c}\text { Both Combined } \\
\left(\text { area m }^{2}\right)\end{array}$ & $\%$ \\
\hline \hline Gravel & 18,146 & 17 & 56,829 & 28 & 74,975 & 24 \\
\hline Medium Cobble & 54,356 & 51 & 106,853 & 53 & 161,209 & 53 \\
\hline Large Cobble & 14,512 & 14 & 12,124 & 6 & 26,636 & 9 \\
\hline Bedrock & 19,883 & 19 & 24,192 & 12 & 44,075 & 14 \\
\hline Grand Total & 106,897 & 100 & 199,998 & 100 & 306,895 & 100 \\
\hline
\end{tabular}

contrast, substrate in the area adjacent to the slump is distributed more predictably across the channel with bedrock in the center and smaller-grained particles toward the margins of the channel. Water velocities likely affect this distribution of substrate.

We estimated milfoil occupied $48 \%$ of the upstream section that was surveyed (Figure 5). We were hindered in our ability to record substrate images within the milfoil; thus, the total available substrate area may be greater than what we estimated. The presence of milfoil in the upper study area leads us to believe that substrate particles are finer, velocity slower, and depths shallower. Although we did not measure velocity, we generally found this to be the case for depth. In general, in areas where milfoil was present, water depths at $100 \mathrm{kcfs}$ were estimated to be less than $3 \mathrm{~m}$ (Figure 6). 


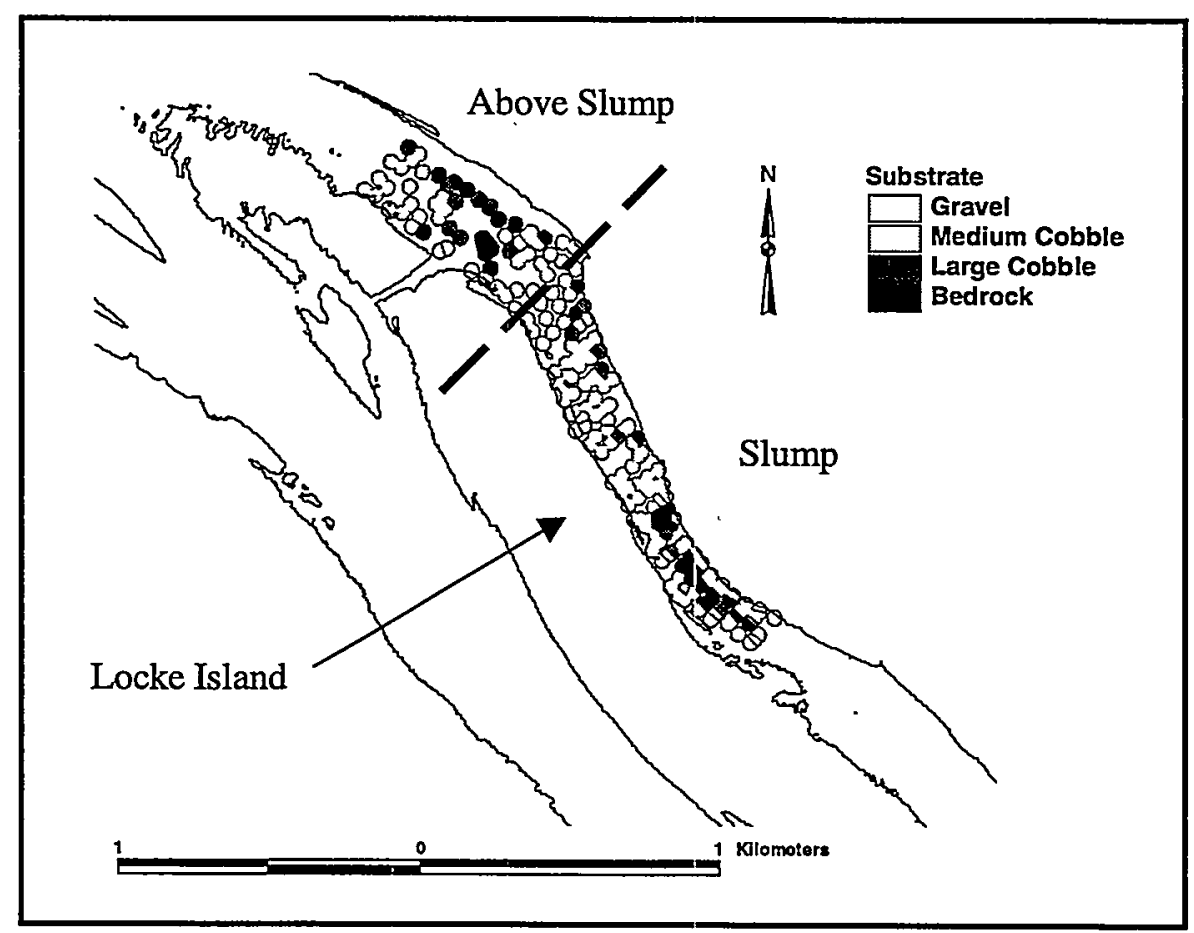

Figure 4. Estimated Distribution of Substrate Occurring Within the Eastern Portion of the Columbia River Near Locke Island

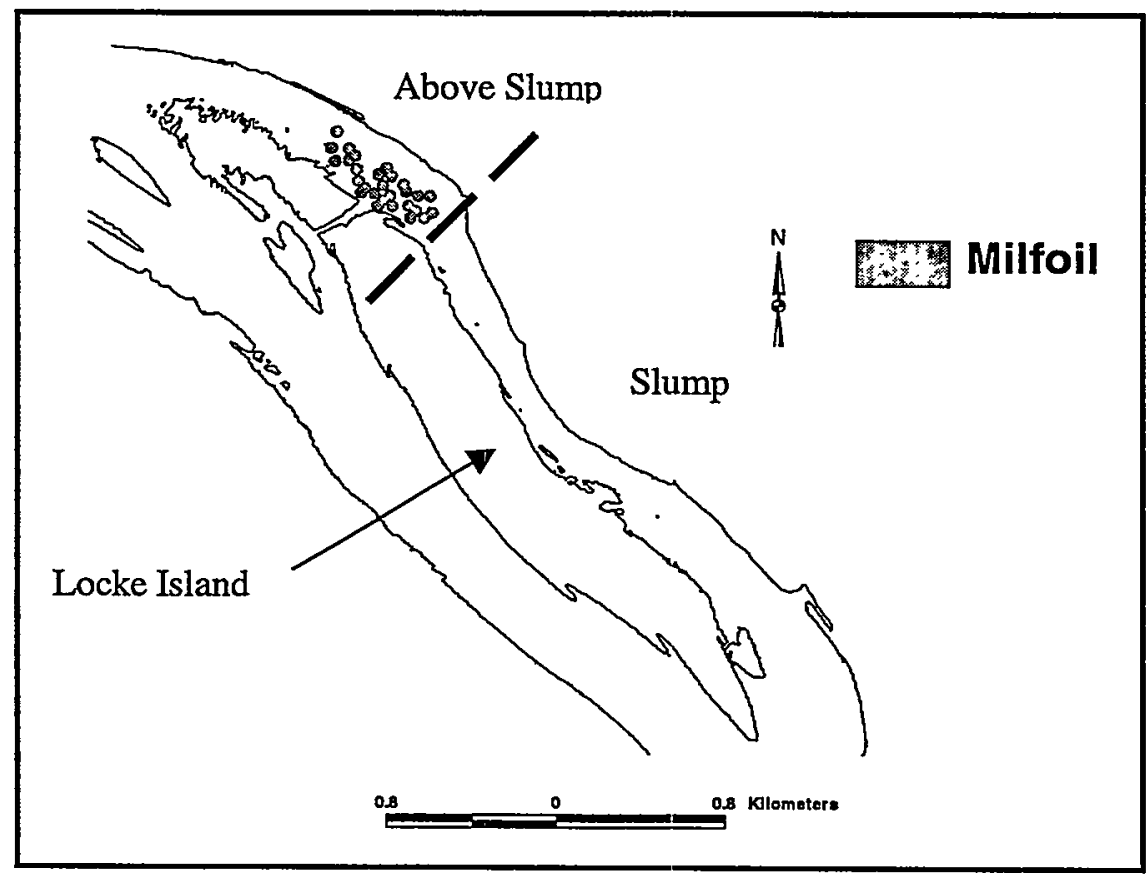

Figure 5. Estimated Distribution of Milfoil Occurring Within the Eastern Portion of the Columbia River Near Locke Island 


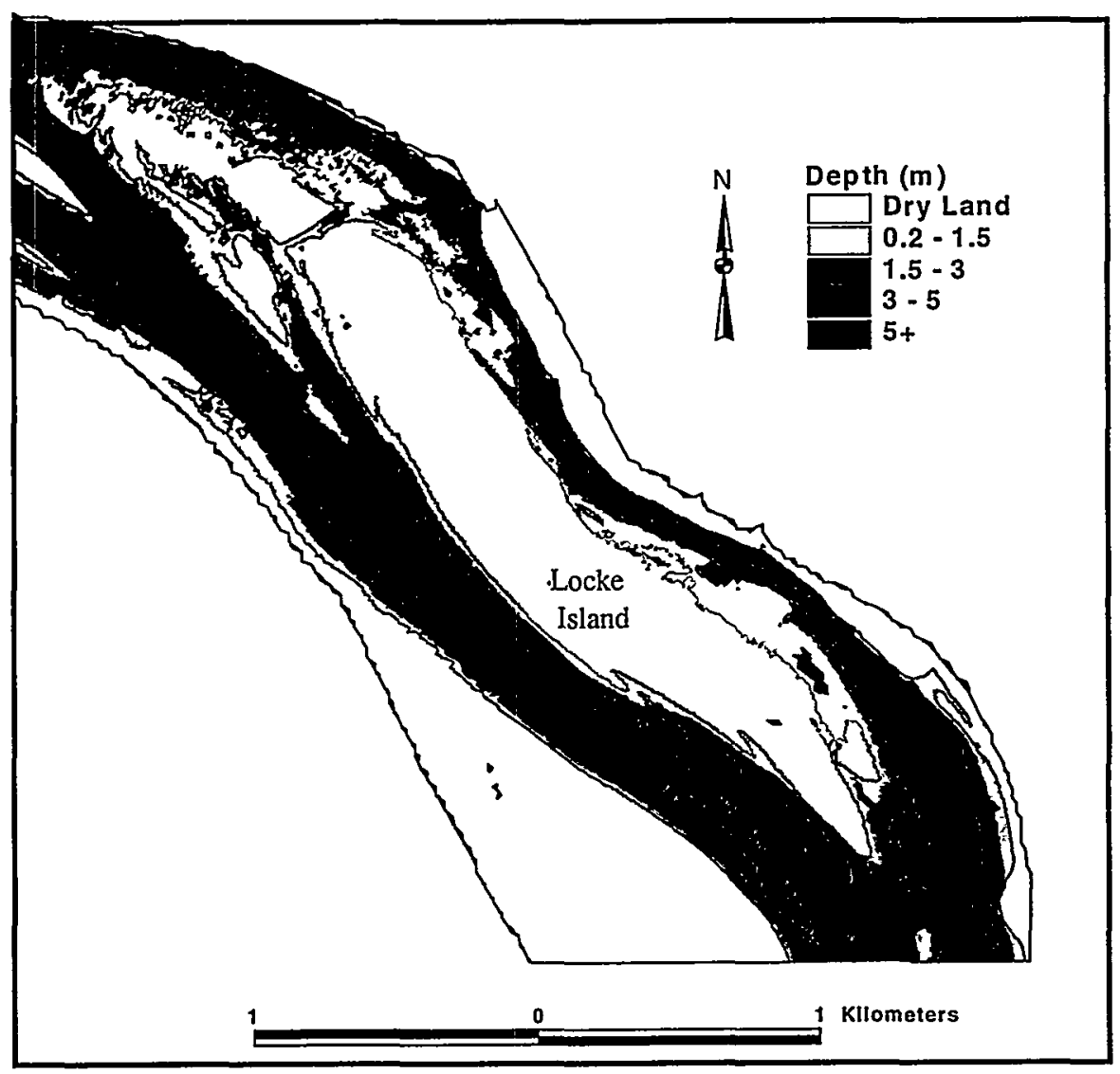

Figure 6. Water Depth Data Gathered Using a Scanning Hydrographic Operational Airborne Lidar Survey System. Data were gathered as part of another project by WDFW and the U.S. Geological Survey. An unsteady flow model was used to project a water surface through the study area at $100 \mathrm{kcfs}$. Depth was determined by subtracting the river bottom elevation from the elevation of the water surface.

Based only on substrate size, we estimated that the best locations for steelhead spawning would be in the middle to lower part of the survey area where substrate was classified as gravel or medium cobble. We estimate that $81 \%$, or approximately $163,680 \mathrm{~m}^{2}$, of the lower section (slump area) surveyed had substrate of suitable size for spawning by steelhead. There is no indication that the material entering the river from the slump is degrading steelhead habitat in the immediate vicinity of the slump. In fact, the slumping may be increasing available habitat by increasing the channel velocities, which in turn scours and cleans gravel and cobble substrate. However, we did not survey downstream of the slump; thus, we have no data on whether fine particles settle out once velocities are reduced. This would negatively affect potential spawning habitat further downstream by reducing streambed particle size, which creates detrimental conditions for salmonid spawning (Platts et al. 1989). 



\subsection{References}

Becker, C.D. 1985. Anadromous Salmonids of the Hanford Reach, Columbia River: 1984 Status. PNL5371, Pacific Northwest Laboratory, Richland, Washington.

Eldred, D. 1970. Steelhead Spawning in the Columbia River, Ringold to Priest Rapids Dam, September 1970 Progress Report. Washington Department of Game, Ephrata, Washington. 4 pp.

Fickeisen, D.H., D.D. Dauble, D.A. Neitzel, W.H. Rickard, R.L. Skaggs, and J.L. Warren. 1980. Aquatic and Riparian Resource Study of the Hanford Reach, Columbia River, Washington. Battelle Pacific Northwest Laboratories, Richland, Washington.

Gray, R.H., and D.D. Dauble. 1976. "Synecology of the Fish Community near Hanford Generating Project and Assessment of Plant Operational Impacts," pp. 5.1 to 5.55. In: Final Report on Aquatic Ecological Studies Conducted at the Hanford Generating Project, 1973-1974. WPPSS Columbia River Ecology Studies Vol. 1. Washington Public Power Supply System, Richland, Washington. 216 pp.

Orcutt, D.R., B.R. Pulliam, and A. Arp. 1968. "Characteristics of Steelhead Trout Redds in Idaho Streams." Trans. Am. Fish. Soc. 97(1):42-45.

Platts, W.S., W.F. Megahan, and G.W. Minshall. 1983. Methods for Evaluating Stream, Riparian, and Biotic Conditions. Technical report INT-138, U.S. Forest Service.

Platts, W.S., R.J. Torquemada, M.L. McHenry, and C.K. Graham. 1989. "Changes in Salmon Spawning and Rearing Habitat from Increased Delivery of Fine Sediment to the South Fork Salmon River, Idaho." Trans. Am. Fish. Soc. 118:274-283.

U.S. Army Corps of Engineers (USACOE). 1998. Locke Island Erosion Control Study. U.S. Department of Energy, DOE/RL-98 0096, Richland, Washington.

Watson, D.G. 1973. Estimate of Steelhead Trout Spawning in the Hanford Reach of the Columbia River. Battelle Pacific Northwest Laboratories, Richland, Washington. 


\section{Distribution}

No. of

Copies

OFFSITE

Bill Gray

USBR

P.O. Box 815

Ephrata, WA 98823

Armand Minthorn

Confederated Tribes of the Umatilla

Indian Reservation

P.O. Box 638

Pendleton, OR 97801

Donna Powaukee

ER/WM Program

Nez Perce Tribe

P.O. Box 365

Lapwai, ID 83540-0365

Jim Russell

ER/WM Program

Yakima Indian Nation

P.O. Box 151

Toppenish, WA 98984

Lenora Seelatsee

Wanapum

P.O. Box 878

Ephrata, WA 98823

Paul Wagner

Washington Department of Fish

and Wildlife

$500 \mathrm{~N}$ Morain Suite 1200B

Kennewick, WA 99336
No. of

Copies

Ronald White

USCOE Walla Walla District

201 North 3rd

Walla Walla, WA 99362

\section{ONSITE}

\section{DOE Richland Operations Office}
K.V. Clarke
A7-75
D.W. Lloyd
A5-15
D.K. Tano
A5-75
D.C. Ward
A5-15

29 Pacific Northwest National Laboratory

D.D. Dauble

K6-85

R.L. Dirkes

K6-75

C.A. Duberstien

K6-85

L.L. Cadwell

K6-85

R.M. Ecker

D.R. Geist (5)

SEQUIM

R.P. Mueller (10)

K6-85

$\mathrm{K} 6-85$

T.M. Poston

K6-75

D.C. Stapp

K6-75

Information Release (7)

K1-06 